\title{
Correction to: IRE1 a deficiency promotes tumor cell death and elF2a degradation through PERK-dependent autophagy
}

Antonello Storniolo ${ }^{1}$, Vincenzo Alfano ${ }^{2}$, Sabino Carbotta ${ }^{3}$, Elisabetta Ferretti ${ }^{1}$ and Livia Di Renzo ${ }^{1,4}$

Correction to: Cell Death Discovery (2018) 4, 3 https:// doi.org/10.1038/s41420-017-0002-9 published online January 29, 2018.

Following publication of the article, author Elisabetta Ferretti asked for the following institution to be added to her affiliation:

Istituto di Ricovero e Cura a Carattere Scientifico Neuromed, Pozzilli, 86077 Isernia, Italy
So the final and correct affiliation for Elisabetta Ferretti is:

Department of Experimental Medicine, Sapienza University, 00161 Rome, Italy

Istituto di Ricovero e Cura a Carattere Scientifico Neuromed, Pozzilli, 86077 Isernia, Italy

The PDF and HTML versions of the paper have been modified accordingly.

Published online: 26 July 2018

Correspondence: Livia Renzo (livia.direnzo@uniroma1.it)

'Department of Experimental Medicine, Sapienza University of Rome, Rome, Italy

${ }^{2}$ Department of Molecular Medicine, Sapienza University of Rome, Rome, Italy

Full list of author information is available at the end of the article.

() 2018 The Author(s).

(c) (i) Open Access This article is licensed under a Creative Commons Attribution 4.0 International License, which permits use, sharing, adaptation, distribution and reproduction in any medium or format, as long as you give appropriate credit to the original author(s) and the source, provide a link to the Creative Commons license, and indicate if changes were made. The images or other third party material in this article are included in the article's Creative Commons license, unless indicated otherwise in a credit line to the material. If material is not included in the article's Creative Commons license and your intended use is not permitted by statutory regulation or exceeds the permitted use, you will need to obtain permission directly from the copyright holder. To view a copy of this license, visit http://creativecommons.org/licenses/by/4.0/. 